\title{
BRCA1 AND BRCA2 GENES MUTATIONS AMONG WOMEN WITH CLINICAL SIGNS OF HEREDITARY BREAST CANCER IN WESTERN BELARUS
}

\author{
Savanevich A. L., Vasilkevich M. I., Abdrashitov V. V., Stepuro T. L.
}

Background: Breast cancer is the most common malignancy in women. In the countries of Central and Eastern Europe founder mutations in the BRCA1 and BRCA2 genes are responsible for a significant proportion of breast cancer cases; however, regional differences in the frequencies of various mutations may occur. The spectrum and frequency of BRCA1 and BRCA2 mutations among breast cancer patients have not yet been fully explored in Belarus.

Aim: In this study, we aimed to estimate the incidence of BRCA1 and BRCA2 causative founder variants in breast cancer female patients with clinical signs of hereditary disease in western Belarus.

Materials and Methods: Blood samples from 71 breast cancer female patients with clinical signs of hereditary disease from the western region of Belarus were examined. We studied 13 causative founder variants in BRCA1 (c.5266dupC, c.4035delA, c.5251C>T, c.181T>G, c.676delT, c.68_69delAG, c.3770_3771delAG, c.1687C>T, c.3756_3759delGTCT) and BRCA2 (c.658_659delGT, c.7910_7914delCCTTT, c.3847_3848delGT, c.5946delT) genes characteristic for the population of Central Europe. The study included 22 female patients with early-onset form, 8 individuals with bilateral and 41 women with multiple primary breast cancer.

Results: 32 out of 71 patients $(45 \%)$ had one of the causative founder variants in the BRCA1 and BRCA2 genes. The most common mutation defined in these genes was BRCA1 c.5266dupC; it was detected in 19 women with breast cancer $(27 \%)$. The carrier of the pathogenic BRCA1 allele c.4035delA was confirmed in 8 cases $(11 \%)$. BRCA1 gene mutations were found to be significantly more common in presence of two or more signs of genetic predisposition to breast cancer. However, among 50 patients with a family medical history of breast and/or ovarian cancer and clinical signs of hereditary cancer, mutations in the BRCA1 and BRCA2 genes were found only in 24 (48 \%) cases.

Conclusion: The study showed high incidence of germinal BRCA1 mutations (45\%) among breast cancer patients in the western region of Belarus. Only two BRCA1 mutations (c.5266dupC, c.4035delA) are detectable in approximately $84 \%$ of carriers. It is necessary to continue studying the mutations in the genes associated with development of breast cancer that are typical for Belarusian population, especially in the group of young female patients, since this study has confirmed the genetic predisposition only in every third patient under the age of 50 .

KEY WORDS: breast cancer, BRCA1 and BRCA2 gene mutations, Belarus

\section{INFORMATION ABOUT AUTHORS}

Alena Savanevich, MD, PhD, Associate Professor, Associate Professor of the Obstetrics and Gynecology Department, Grodno State Medical University; 80, Gorki str., Grodno, Belarus, 230009, e-mail: elena.savonevich@icloud.com, ORCID ID: https://orcid.org/0000-0002-3661-2354

Maryia Vasilkevich, Internship doctor, Grodno University Clinic; 52, Boulevard of Lenin Komsomol, Grodno, Belarus, 230017, e-mail: mariaaaws@ gmail.com, ORCID ID: https://orcid.org/0000-0001-5959-9546

Vitalii Abdrashitov, Junior Researcher, Scientific Research Laboratory Scientific and Organizational Department, Grodno State Medical University; 80, Gorki str., Grodno, Belarus, 230009, e-mail: dubrovski1917@gmail.com, ORCID ID: https://orcid.org/0000-0002-3500-6563

Tatiana Stepuro, Ph.D. in Biology, Associate Professor of the Department of Normal Physiology, Grodno State Medical University, e-mail: mikhno_t@ yahoo.com ORCID ID: https://orcid.org/0000-0002-3337-4231

The beginning of the XXI century was marked by a significant increase in female breast cancer cases. This disease is the most common among all malignant neoplasms in women. Breast cancer morbidity has increased by $50 \%$ over the last 20 years [1]. New methods of diagnostics and screening of breast cancer are being developed and introduced into clinical practice, but this pathology incidence and mortality rates continue to grow steadily. The last decade has been marked by the rapid development of oncogenetics and especially by breast cancer genetics. The study of families with autosomal inherited predisposition to one or more types of cancer pathology revealed 
several breast cancer predisposition genes [2, $3]$. Hereditary mutations are the cause of breast cancer in $10-15 \%$ of cases [4, 5]. Such forms of cancer are characterized by early age of disease development (on average, 15 years earlier than in the general population), high frequency of bilateral and multiple primary lesions, Mendelian laws of inheritance, prognostic factors, and require individual diagnostic and therapeutic approach [6, 7]. Thus, special attention should be paid to the examination of women in the following cases:

- aggravated family medical history (presence of two or more relatives with reproductive system cancer)

- vertical transmission of the disease in the family (mother/daughter)

- presence of family members with multiple primary tumors, including damage to paired organs (bilateral breast cancer)

- presence of family members diagnosed with cancer at a young age (up to 40 years)

- presence of family members with an unusually favorable course of the disease, even at advanced stages

- presence of signs of hereditary syndromes in the family - Gardner syndrome, Peitz-Jaegers syndrome, nevoid basal cell carcinoma, Stein-Leventhal syndrome, Turner syndrome, neurofibromatosis.

The examination for suspected hereditary cancer syndrome begins with collection of oncological history from relatives and compilation of a pedigree. When drawing up pedigrees, localization of tumors, the age of occurrence of the disease and the presence of multiple primary forms of tumors are taken into account. The next stage is laboratory diagnostics. DNA analysis of mutations provides confirmation of the genetic predisposition to cancer and risk assessment of the pathology development in relatives. It allows determining the disease management tactics, the possibility of disease prevention and its early diagnosis. A single genetic test has a life-long informational value.

Currently, the genes associated with the development of cancer include BRCA1, BRCA2, CHEK2, p53, ATM, and NBS1 genes [8]. The role of the BRCA1 and BRCA2 genes in the occurrence of malignant neoplasms in the mammary gland has been studied most fully. According to the present understanding, the BRCA1 and BRCA2 genes act as classic tumor suppressors. The function of these genes is involved in the repair of double-stranded DNA breaks by homologous recombination, which is necessary to maintain the stability of the genome [9]. A breakdown in the BRCA1 gene is primarily associated with the development of hereditary breast and ovarian cancer syndrome (HBOC - hereditary breast ovarian cancer). Loss of BRCA2 gene function is associated with hereditary breast cancer syndrome (HBC - hereditary breast cancer). Among women with a germinal mutation of one of the alleles of the BRCA1 gene, the risk of developing breast cancer during the lifetime is associated with age and reaches $55-70 \%$ by the age of 70 years, $72 \%$ by the age of 80 years. For carriers of a mutation in the BRCA2 gene the risk of developing breast cancer is $45-70 \%$. At the same time, the risk of developing breast cancer in the general population does not exceed $12 \%$. The highest incidence of breast cancer in carriers of a BRCA1 gene mutation occurs at the age of 30 to 40 years $[10,11]$.

If a mutation carrier has an aggravated family history, the risk of developing a tumor in the breast increases up to $87 \%$ for BRCA1 gene mutation carriers, up to $84 \%$ for BRCA2 mutation carriers. The risk of contralateral breast cancer in mutation carriers correlates with the young age of the first tumor detection, localization of the gene mutation, Tamoxifen intake and bilateral oophorectomy. L. Verhoog et al. have estimated the annual risk of developing contralateral breast cancer for BRCA1associated cancer patients younger than 41 years as $4.5 \%$. When breast cancer manifests in BRCA1 mutation carriers under the age of 40 , the risk of developing contralateral breast cancer in the next 25 years is $63 \%$ or more. If the disease develops for the first time in women over 50 years of age, the risk of developing contralateral breast cancer does not exceed $19.6 \%$ [12, 13].

The previous studies of the incidence of several mutations in breast cancer patients in our country were of isolated nature. However, they made it possible to establish a significant «founder effect» for the BRCA1 c.5266dupC $[14,15]$ mutation in the population of Belarus.

The aim of the study is to estimate the incidence of BRCA1 and BRCA2 causative founder variants in breast cancer female patients with clinical signs of hereditary disease in western Belarus. To increase the likelihood of detecting genetic breakdowns associated with the development of breast cancer, we have focused our attention on patients with early, bilateral, and multiple primary cancers [6]. 


\section{MATERIALS AND METHODS}

The study included 22 female patients with the early-onset form (up to 50 years of age), 8 individuals with bilateral and 41 patients with multiple primary breast cancer. All the women were treated at Grodno State Medical University Clinic. Patient involvement in the research process was implemented in compliance with the principles of voluntariness and confidentiality with the registration of informed consent to participate in the study.

All DNA samples were isolated from peripheral blood leukocytes. The analysis of 13 causative founder mutations in the BRCA1 genes (c.5266dupC, c.4035delA, c. $5251 \mathrm{C}>\mathrm{T}, \quad$ c. $181 \mathrm{~T}>\mathrm{G}, \quad$ c.676delT, c.68_69delAG, c.3770_3771delAG, c.1687C $>$ T, c.3756_3759delGTCT) and BRCA2 (c.658_659delGT,

c.7910_7914delCCTTT, c.3847_3848delGT, c.5946delT) was performed. Mutations of c.5266dupC and c.4035delA in the BRCA1 gene were determined by allele-specific oligonucleotide polymerase chain reaction. Other mutations of BRCA1 (c.5251C $>\mathrm{T}$, c.181T $>$ G, c.676delT, c.68_69delAG, c.3770_3771delAG, c.1687C>T,

c.3756_3759delGTCT) and BRCA2 (c.658_659delGT, c.7910_7914delCCTTT, c.3847_3848delGT, c.5946delT) were genotyped using TaqMan kits (Applied Biosystems/Life Technologies, Carlsbad, CA) on a Roche LightCycler 480. For obtained results validation, direct Sanger DNA sequencing was performed. The BigDye Terminator v3.1 Cycle Sequencing Kit (Life Technologies) was used in accordance with manufacturer's protocol. The sequencing results were analyzed using the ABI Prism 3100 genetic analyzer (Life Technologies).

\section{RESULTS}

The average age of 71 patients involved in the study was $45.4 \pm 9.2$ years. In the group of 22 women (28 to 50 years) with monolateral cancer diagnosed at the age of under 50 years, the average age of the disease was $41.2 \pm 7.4$ years. Every second patient had an aggravated medical family history of breast cancer and/or ovarian cancer in the first or second degree relatives. Out of 8 women with bilateral breast cancer, only two developed tumors synchronously. The average age of development of the first tumor was $42.4 \pm 9.4$ years ( 31 to 59 years), and that of the contralateral neoplasm was $48.3 \pm 11.1$ years (40 to 68 years). Only 3 patients had indirect signs of hereditary cancer. Time interval between first and second tumors in the mammary glands was from 1 to 17 years, $8.2 \pm 5.3$ years on average. The group with multiple primary breast cancers consisted of 4 synchronous and 37 metachronous cases. The average age of breast cancer detection was $48.4 \pm 9$ years (32 to 73 years), while only 3 women had breast cancer as a second diagnosed tumor. The multiplicity of primary neoplasms in most cases was represented by two localizations $-28(68 \%)$, less often - by three 12 (29\%). Only 1 patient was diagnosed with four tumors with 7 to 9 years intervals, with first tumor occurring in the mammary gland at the age of 39. Most often, the development of malignant neoplasms in mammary glands was combined with ovarian cancer -39 cases $(95 \%)$, or uterine cancer- 3 $(7 \%)$. Bilateral breast tumors in the group of patients with multiple primary cancer occurred in 9 women (22\%). Interval between development of breast cancer and appearance of another neoplasm ranged from 1 year to 19 years, with an average of $7.7 \pm 5$ years. During the first five years, new malignant neoplasm appeared in 13 women (32\%), with interval of 5 to 10 years of follow-up- in $11(27 \%)$, after 10-15 years in $7(17 \%)$. In 6 other patients, tumors of a different localization were diagnosed 15-19 years later $(15 \%)$. 23 women with polyneoplasia $(56 \%)$ had a family history of breast cancer and/or ovarian cancer of the first or second line of kinship.

The study revealed that 32 out of 71 female patients $(45 \%)$ had one of the germinal mutations in the BRCA1 and BRCA2 genes. The most common mutation was BRCA1 c.5266dupC which was detected in 19 women with breast cancer $(27 \%)$. The carrier of the pathogenic BRCA1 c.4035delA allele was confirmed in 8 cases $(11 \%)$. Two patients had a BRCA2 c.658_659delGT mutation (3\%). Three patients with multiple primary cancer had isolated cases of other genetic defects in the BRCA1 gene (4\%). The average age in the group of mutation carriers was $43.4 \pm 9.3$ years (from 30 to 73 years). In the group of patients without mutations, the average age of breast cancer 
was higher $-47.2 \pm 8.8$ years (28 to 68 years). Among 22 young women with monolateral breast cancer, the germinal mutation was detected in only 7 cases ( $32 \%)$, and BRCA1 c.5266dupC was identified in all seven of them. Hereditary mutations were present in 3 out of 8 women $(38 \%)$ with bilateral breast cancer and in 22 out of 41 women with primary multiple cancer $(54 \%)$.
Patients with polyneoplasia were found to have mutations of c.5266dupC and c.4035delA in the BRCA1 gene with approximately the same frequency-in $24 \%$ and $20 \%$ of cases, respectively (Table 1 ). One woman with esophageal cancer at 65 , breast cancer at 73 , and colorectal cancer at 84 was found to have the BRCA2 c.658_659delGT mutation.

The frequency of causative founder BRCA1 and BRCA2 mutations in patients with breast cancer

\begin{tabular}{|c|c|c|c|c|}
\hline $\begin{array}{l}\text { BRCA1/BRCA2 } \\
\text { mutation type }\end{array}$ & $\begin{array}{c}\text { Bilateral } \\
\text { breast cancer, } \\
\quad \mathbf{n}=\mathbf{8}\end{array}$ & $\begin{array}{l}\text { Multiple primary } \\
\text { breast cancer, } \\
\text { n }=\mathbf{4 1}\end{array}$ & $\begin{array}{l}\text { Early onset } \\
\text { breast cancer, } \\
\quad n=22\end{array}$ & $\begin{array}{l}\text { Total, } \\
\mathrm{n}=71\end{array}$ \\
\hline BRCA1 c.5266dupC & 2 & 10 & 7 & 19 \\
\hline BRCA1 c.4035delA & - & 8 & - & 8 \\
\hline BRCA1c.3847_3848delGT & - & 1 & - & 1 \\
\hline BRCA1c.3770_3771delAG & - & 1 & - & 1 \\
\hline BRCA1 c.181T>G & - & 1 & - & 1 \\
\hline BRCA2 c.658_659delGT & 1 & 1 & - & 2 \\
\hline Total & $3(37,5 \%)$ & $22(54 \%)$ & $7(32 \%)$ & $32(45 \%)$ \\
\hline
\end{tabular}

We evaluated the relation between the probability of mutation identification and the number of indirect clinical signs of hereditary breast cancer (early-onset form of the disease, bilateralism, family and personal history of cancer). BRCA1 gene mutations were found to be significantly more common in presence of two or more signs of genetic predisposition to breast cancer (Table 2).

However, among 50 patients with a family medical history of breast and/or ovarian cancer in first or second degree relatives and clinical signs of hereditary cancer, mutations in the BRCA1 and BRCA2 genes were found only in $24(48 \%)$ cases. This indicates the need for the patients to undergo an in-depth genetic examination, including determination of the complete nucleotide sequence of genes associated with the development of breast cancer, including BRCA1 and BRCA2. Obviously, these methods are much more complex, more expensive and require serious resources like classical Sanger and the nextgeneration sequencing methods and highly qualified personnel. 
Incidence of BRCA1 and BRCA2 mutations in breast cancer by the number of indirect clinical signs of hereditary disease.

\begin{tabular}{|c|c|c|c|c|}
\hline $\begin{array}{l}\text { Clinical signs } \\
\text { of hereditary breast cancer }\end{array}$ & $\begin{array}{l}\text { Total, } \\
\mathbf{N}=71\end{array}$ & $\begin{array}{l}\text { BRCA1 } \\
\text { mutation }\end{array}$ & $\begin{array}{l}\text { BRCA2 } \\
\text { mutation }\end{array}$ & $\begin{array}{l}\text { BRCA1/BRCA2 } \\
\text { mutation types }\end{array}$ \\
\hline \multicolumn{5}{|c|}{4 clinical signs } \\
\hline $\begin{array}{l}\text { Bilateral breast cancer + early- } \\
\text { onset breast cancer + personal } \\
\text { history of cancer }+ \\
\text { family history of breast/ovarian } \\
\text { cancer }\end{array}$ & 6 & 3 & 1 & $\begin{array}{l}\text { BRCA1 c.5266dupC -2 } \\
\text { BRCA1 c.4035delA } \\
\text { BRCA2 c.658_659delGT }\end{array}$ \\
\hline \multicolumn{5}{|c|}{3 clinical signs } \\
\hline $\begin{array}{l}\text { Bilateral breast cancer + early- } \\
\text { onset breast cancer+ personal } \\
\text { history of cancer }\end{array}$ & 8 & 2 & - & BRCA1 c.5266dupC -2 \\
\hline $\begin{array}{l}\text { Early-onset breast cancer }+ \\
\text { personal history of cancer }+ \\
\text { family history of breast/ovarian } \\
\text { cancer }\end{array}$ & 2 & 1 & - & BRCA1 c.3847_3848delGT \\
\hline \multicolumn{5}{|c|}{2 clinical signs } \\
\hline $\begin{array}{l}\text { Early-onset breast cancer }+ \\
\text { family history of breast/ovarian } \\
\text { cancer }\end{array}$ & 22 & 12 & - & $\begin{array}{l}\text { BRCA1 c. } 5266 \text { dupC - } 8 \\
\text { BRCA1 c. } 4035 \text { delA - } 3 \\
\text { BRCA1 c. } 181 T>G\end{array}$ \\
\hline \multicolumn{5}{|c|}{1 clinical sign } \\
\hline Early-onset breast cancer & 17 & 7 & - & $\begin{array}{l}\text { BRCA1 c.5266dupC }-5 \\
\text { BRCA1 c.4035delA -2 }\end{array}$ \\
\hline $\begin{array}{l}\text { Family history of breast/ovarian } \\
\text { cancer }\end{array}$ & 4 & 1 & - & BRCA1 c.4035delA \\
\hline Personal history of cancer & 1 & - & 1 & BRCA2 c.658_659delGT \\
\hline \multicolumn{5}{|c|}{ Absence of clinical signs } \\
\hline $\begin{array}{l}\text { Breast cancer in women over } 50 \\
\text { years of age }\end{array}$ & 8 & 4 & - & $\begin{array}{l}\text { BRCA1 c.5266dupC }-2 \\
\text { BRCA1 c. } 4035 \text { delA } \\
\text { BRCA1 c. } 3770 \_3771 \text { delAG }\end{array}$ \\
\hline
\end{tabular}

\section{DISCUSSION}

In the present study, 13 causative founder variants of BRCA1 and BRCA2 genes have been analyzed in the selected breast cancer patients from Grodno region of Belarus. We have detected that approximately $45 \%$ (32 out of 71 cases) of breast cancer female patients with clinical signs of hereditary disease carried one of only six germinal mutations in the BRCA1 or BRCA2 gene. This has been the third study of BRCA mutations in breast cancer in Belarus. In our previous study we observed three BRCA1 founder mutations only in 38 of 500 (7.6\%) unselected breast cancer patients [14]. Bogdanova and her colleagues reported that any of the three mutations were identified in 
countries of Central and Eastern Europe may be attributed to the low migration rate. The mean age of breast cancer diagnosis of the 32 cases with BRCA1 or BRCA2 mutations was $43.4 \pm 9.3$ years, which is slightly higher than it is in other regions.

There are some limitations to our study. Due to the small sample size of the analyzed series we were not able to provide conclusive data on the full spectrum of BRCA1 and BRCA2 mutations in breast cancer patients. We screened 71 breast cancer female patients for 13 causative founder mutations in BRCA1 and BRCA 2 genes, but detected only 6 of them. It is possible therefore that the other germinal variants were missed. Further studies based on the sequential testing of BRCA1 and BRCA2 genes as well as other genes that may be associated with a strong predisposition to breast cancer should be carried on. At the same time, identification of several «major» mutations in all the patients with breast cancer is a realistic task for medical institutions at the regional level. Thus, a significant number of hereditary BRCA-associated breast cancers in our region can be detected by a small number of PCR tests. We foresee that target screening of specific causative variants in BRCA1 and BRCA2 genes restricted to a particular ethnic group would be more effective in the future therapeutic approaches for the prevention and cure of breast cancer. The use of this diagnostic approach and preventive riskreducing surgery may contribute to the future reduction of morbidity and mortality from breast cancer in Belarus.

\section{CONCLUSIONS}

The study showed high incidence of germinal BRCA1 mutations (45\%) among breast cancer patients in western Belarus. It should be noted that only two BRCA1 mutations (c.5266dupC, c.4035delA) are detectable in approximately $84 \%$ of carriers. It is necessary to continue studying the mutations in the genes associated with development of breast cancer that are typical for Belarusian population, especially in the group of young female patients, since this study has confirmed the genetic predisposition only in every third patient under the age of 50 .

The study was supported by the Belarusian Republican Foundation for Fundamental Research, grant No. M20R-400.

This research was fulfilled in collaboration with colleagues from the International Hereditary Cancer Center, Department of Genetics and Pathology, headed by Professor J. Lubinski, at Pomeranian Medical University in Szczecin (Poland). We are particularly grateful to Professor J. Gronwald and Dr. A. Ashurek for the cooperation.

\section{REFERENCES}

1. Paluch-Shimon S, Cardoso F, Sessa C, Balmana J, Cardoso MJ, Gilbert F, Senkus E; ESMO Guidelines Committee. Prevention and screening in BRCA mutation carriers and other breast/ovarian hereditary cancer syndromes: ESMO Clinical Practice Guidelines for cancer prevention and screening. Ann Oncol. 2016 Sep; 27 (suppl 5): v103-v110. https://doi.org/10.1093/annonc/mdw327. Erratum in: Ann Oncol. 2017 Jul 1; 28 (suppl_4): iv167-iv168. PMID: 27664246.

2. Valencia OM, Samuel SE, Viscusi RK, Riall TS, Neumayer LA, Aziz H. The Role of Genetic Testing in Patients With Breast Cancer: A Review. JAMA Surg. 2017 Jun 1; 152 (6): 589-594. https://doi.org/10.1001/jamasurg.2017.0552. PMID: 28423155.

3. Cohen-Haguenauer O. Prédisposition héréditaire au cancer du sein (1) - Génétique [Hereditary predisposition to breast cancer (1): genetics]. Med Sci (Paris). 2019 Feb; 35 (2): 138-151. French. https://doi.org/10.1051/medsci/2019003. Epub 2019 Feb 18. PMID: 30774081.

4. Armstrong N, Ryder S, Forbes C, Ross J, Quek RG. A systematic review of the international prevalence of BRCA mutation in breast cancer. Clin Epidemiol. 2019 Jul 11; 11: 543-561. https://doi.org/10.2147/CLEP.S206949. PMID: 31372057 ; PMCID: PMC6628947.

5. Grindedal EM, Heramb C, Karsrud I, Ariansen SL, Mæhle L, Undlien DE, Norum J, Schlichting E. Current guidelines for BRCA testing of breast cancer patients are insufficient to detect all mutation carriers. BMC Cancer. 2017 Jun 21; 17 (1): 438. https://doi.org/10.1186/s12885-017-3422-2. PMID: 28637432; PMCID: PMC5480128.

6. Moyer VA; U.S. Preventive Services Task Force. Risk assessment, genetic counseling, and genetic testing for BRCA-related cancer in women: U.S. Preventive Services Task Force recommendation statement. Ann Intern Med. 2014 Feb 18; 160 (4): 271-81. https://doi.org/10.7326/M13-2747. PMID: 24366376. 
7. Kemp Z, Turnbull A, Yost S, Seal S, Mahamdallie S, Poyastro-Pearson E, Warren-Perry M, Eccleston A, Tan MM, Teo SH, Turner N, Strydom A, George A, Rahman N. Evaluation of Cancer-Based Criteria for Use in Mainstream BRCA1 and BRCA2 Genetic Testing in Patients With Breast Cancer. JAMA Netw Open. 2019 May 3; 2 (5): e194428. https://doi.org/10.1001/jamanetworkopen.2019.4428. PMID: 31125106; PMCID: PMC6632150.

8. Germline Mutations in Cancer Susceptibility Genes in a Large Series of Unselected Breast Cancer Patients / J. Sun [et al.] // Clin. Cancer Res. 2017; 23 (20): 6113-6110. https://doi.org/10.1158/1078-0432.CCR-163227.

9. Paterson R, Phillips KA. Genetic testing in women with breast cancer: implications for treatment. Expert Rev Anticancer Ther. 2017; Nov; 17 (11): 991-1002. https://doi.org/10.1080/14737140.2017.1374175. Epub 2017 Sep 8. PMID: 28853307.

10. Risks of breast, ovarian and contralateral breast cancer for BRCA1 and BRCA2 mutation carriers / K. B. Kuchenbaecker [et al.] // JAMA. 2017; 317 (23): 2402-2416.

11. Average risks of breast and ovarian cancer associated with BRCA1 or BRCA2 mutations detected in case series unselected for family history: a combined analysis of 22 studies / A. Antoniou [et al.] // Am J Hum Genet. 2003; 72 (5): 1170-1130.

12. New malignancies among cancer survivors: SEER Cancer Registries, 1973-2000. [Electronic resource] / ed.: R. E. Curtis [et al.]. National Cancer Institute, 2006. $492 \mathrm{p}$. Mode of access: http://seer.cancer.gov/archive/publications/mpmono/. Date of access: 18.12.2020.

13. Contralateral breast cancer risk in BRCA1 and BRCA2 mutation carriers / M. K. Graeser [et al.] // J Clin Oncol. 2009; 27 (35): 5887-5892.

14. The contribution of founder mutations in BRCA1 to breast cancer in Belarus / N. Uglanitsa [et al.] // Clin Genet. 2010;78(4):377-380. https://doi.org/10.1111/j.1399-0004.2010.01439.x

15. High frequency and allele-specific differences of BRCA1 founder mutations in breast cancer and ovarian cancer patients from Belarus / N. V. Bogdanova [et al.] // Clin Genet. 2010; 78 (4): 364-372. https://doi.org/10.1111/j.1399-0004.2010.01473.x

\section{МУТАЦÏ̈ ВRСА1 I ВRСА2 ГЕНІВ У ЖІНОК 3 КЛІНІЧНИМИ ОЗНАКАМИ СПАДКОВОГО РАКУ МОЛОЧНОЇ ЗАЛОЗИ У ЗАХІДНОМУ РЕГІОНІ БІЛОРУСІ}

Савоневіч О. Л., Василькевич М. І., Абдрашитов В. В., Степура Т. Л.

Вступ. Рак молочної залози лідирує серед усіх злоякісних новоутворень у жінок. У країнах Центральної та Східної Європи спадкові мутації BRCA1 і BRCA2 генів є однією з провідних причин розвитку раку молочної залози; однак, мають місце і регіональні особливості в частоті різних мутацій. Раніше в Білорусі не проводилося дослідження широкого спектра і частоти виникнення гермінальних мутацій BRCA1 і BRCA2 генів у пацієнток з раком молочної залози.

Мета. Встановити поширеність гермінальних мутацій BRCA1 і BRCA2 генів серед пацієнток 3 клінічними ознаками спадкового раку молочної залози в Білорусі.

Матеріали та методи. Досліджено зразки крові 71 жінок з раком молочної залози і клінічними ознаками спадкового раку, які постійно проживають в західному регіоні Білорусі. Виконано аналіз 13 значущих для населення Центральної Європи мутацій засновника в генах BRCA1 (c.5266dupC, c.4035delA, c.5251C> T, c.181T> G, c.676delT, c.68_69delAG, c.3770_3771delAG, c.1687C> T, c.3756_3759delGTCT) i BRCA2 (c.658_659delGT, c.7910_7914delCCTTT, с.3847_3848delGT, c.5946delT). У дослідження включені 22 пацієнтки з раннім монолатеральним раком молочної залози (до 50 років включно), 8 - з білатеральним і 41 жінка з первинно-множинним раком молочної залози.

Результати. У 32 з 71 пацієнток (45\%) була виявлена одна із значущих патогенних мутацій в генах BRCA1 i BRCA2. Частіше за інших зустрічалася мутація BRCA1 с.5266dupC - вона була виявлена у 19 жінок з раком молочної залози (27 \%). Носійство патогенного алелі BRCA1 c.4035delA було підтверджено в 8 випадках (11\%). Встановлено, що мутації гена BRCA1 зустрічалися достовірно частіше при наявності двох і більше ознак генетичної схильності до раку молочної залози. Разом 3 тим, серед 50 пацієнток з обтяженим сімейним анамнезом по раку молочної залози i/або раку яєчників і клінічними ознаками спадкового раку мутації в генах BRCA1 і BRCA2 були виявлені тільки у 24 (48\%) осіб.

Висновки. Встановлено високу частоту зустрічальності гермінальних мутацій гена BRCA1 (45 \%) у пацієнток з раком молочної залози в західному регіоні Білорусі. становить 25 \%. Найбільш поширеними є мутації с.5266dupC і c.4035delA в гені BRCA1, вони були виявлені у 84 \% в групі носіїв. Необхідно продовжити вивчення типових для населення Білорусі мутацій в генах, асоційованих 
3 розвитком раку молочної залози, особливо в групі молодих пацієнток, так як справжнім дослідженням генетична схильність підтверджена тільки у кожної третьої пацієнтки у віці до 50 років.

КЛЮЧОВІ СЛОВА: рак молочної залози, мутації гена BRCA1, BRCA2, Білорусь

\section{ІНФОРМАЦІЯ ПРО АВТОРІВ}

Савоневіч Олена Леонтіївна, к. мед. н., доцент кафедри акушерства і гінекології, УО «Гродненський державний медичний університет»; вул. Горького, 80, Гродно, Білорусь, 230009, e-mail: elena.savonevich@icloud.com, ORCID ID: https://orcid.org/0000-0002-3661-2354

Василькевич Марія Ігорівна, лікар-стажист У3 «Гродненська університетська клініка»; Бульвар Ленінського Комсомолу, 52, Гродно, Білорусь, 230017, e-mail: mariaaaws@ gmail.com, ORCID ID: https://orcid.org/0000-00015959-9546

Абдрашітов Віталій В'ячеславович, м. н. с., науково-дослідної лабораторії науково-дослідної частини, УО «Гродненський державний медичний університет»; вул. Горького, 80, Гродно, Білорусь, 230009, e-mail: dubrovski1917@gmail.com, ORCID ID: https://orcid.org/0000-0002-3500-6563

Степура Тетяна Леонідівна, к. біол. н., доцент кафедри нормальної фізіології УО «Гродненський державний медичний університет», вул. Горького, 80, Гродно, Білорусь, 230009, e-mail: mikhno_t@yahoo.com, ORCID ID: https://orcid.org/0000-0002-3337-4231

\section{МУТАЦИИ ВRСА1 И ВRСА2 ГЕНОВ У ЖЕНЩИН С КЛИНИЧЕСКИМИ ПРИЗНАКАМИ НАСЛЕДСТВЕННОГО РАКА МОЛОЧНОЙ ЖЕЛЕЗЫ В ЗАПАДНОМ РЕГИОНЕ БЕЛАРУСИ}

\section{Савоневич Е. Л., Василькевич М. И., Абдраиитов В. В., Степуро Т. Л.}

Введение. Рак молочной железы лидирует среди всех злокачественных новообразований у женщин. В странах Центральной и Восточной Европы наследственные мутации BRCA1 и BRCA2 генов являются одной из ведущих причин развития рака молочной железы; однако, имеют место и региональные особенности в частоте встречаемости различных мутаций. Ранее в Беларуси не проводилось исследование широкого спектра и частоты встречаемости герминальных мутаций BRCA1 и BRCA2 генов у пациенток с раком молочной железы.

Цель. Установить распространенность герминальных мутаций BRCA1 и BRCA2 генов среди пациенток с клиническими признаками наследственного рака молочной железы в Беларуси.

Материалы и методы. Исследованы образцы крови 71 женщины с раком молочной железы и клиническими признаками наследственного рака, постоянно проживающих в западном регионе Беларуси. Выполнен анализ 13 значимых для населения Центральной Европы мутаций основателя в генах BRCA1 (c.5266dupC, c.4035delA, c.5251C>T, c.181T > G, c.676delT, c.68_69delAG, c.3770_3771delAG, с.1687C > T, с.3756_3759delGTCT) и c.7910_7914delCCTTT, с.3847_3848delGT, c.5946delT). В исследование включены 22 пациентки с ранним монолатеральным раком молочной железы (до 50 лет включительно), 8 - с билатеральным и 41 женщина с первично-множественным раком молочной железы.

Результаты. У 32 из 71 пациенток (45 \%) была обнаружена одна из значимых патогенных мутаций в генах BRCA1 и BRCA2. Чаще других встречалась мутация BRCA1 с.5266dupC - она была выявлена у 19 женщин с раком молочной железы (27\%). Носительство патогенного аллеля BRCA1 c.4035delA было подтверждено в 8 случаях (11\%). Установлено, что мутации гена BRCA1 встречались достоверно чаще при наличии двух и более признаков генетической предрасположенности к раку молочной железы. Вместе с тем, среди 50 пациенток с отягощенным семейным анамнезом по раку молочной железы и/или раку яичников и клиническими признаками наследственного рака мутации в генах BRCA1 и BRCA2 были обнаружены только у 24 (48 \%) человек.

Выводы. Установлена высокая частота встречаемости герминальных мутаций гена BRCA1 (45 \%) у пациенток с раком молочной железы в западном регионе Беларуси. составляет 25 \%. Наиболее распространенными являются мутации с.5266dupC и c.4035delA в гене BRCA1, они были обнаружены у $84 \%$ в группе носителей. Необходимо продолжить изучение типичных для населения Беларуси мутаций в генах, ассоциированных с развитием рака молочной железы, особенно в группе молодых пациенток, так как настоящим исследованием генетическая предрасположенность подтверждена только у каждой третьей пациентки в возрасте до 50 лет.

КЛЮЧЕВЫЕ СЛОВА: рак молочной железы, мутации гена BRCA1, BRCA2, Беларусь 


\section{ИНФОРМАЦИЯ ОБ АВТОРАХ}

Савоневич Елена Леонтьевна, к. мед. н., доцент кафедры акушерства и гинекологии, УО «Гродненский государственный медицинский университет»; ул. Горького, 80, Гродно, Беларусь, 230009, e-mail: elena.savonevich@icloud.com, ORCID ID: https://orcid.org/0000-0002-3661-2354

Василькевич Мария Игоревна, врач-стажер УЗ «Гродненская университетская клиника»; Бульвар Ленинского Комсомола, 52, Гродно, Беларусь, 230017, e-mail: mariaaaws@ gmail.com, ORCID ID: https://orcid.org/0000-00015959-9546

Абдрашитов Виталий Вячеславович, м. н. с., научно-исследовательской лаборатории научно-исследовательской части, УО «Гродненский государственный медицинский университет»; ул. Горького, 80, Гродно, Беларусь, 230009, e-mail: dubrovski1917@gmail.com, ORCID ID: https://orcid.org/0000-0002-3500-6563

Степуро Татьяна Леонидовна, к. биол. н., доцент кафедры нормальной физиологии УО «Гродненский государственный медицинский университет», ул. Горького, 80, Гродно, Беларусь, 23000, e-mail: mikhno_t@yahoo.com, ORCID ID: https://orcid.org/0000-0002-3337-4231

Conflicts of interest: author has no conflict of interest to declare.

Конфлікт інтересів: відсутній.

Конфликт интересов: отсутствует.

Отримано: 24.02.2021 року

Прийнято до друку: 17.05.2021 року 